\title{
Efektivitas minuman kombinasi maltodekstrin dan vitamin C terhadap hitung jenis leukosit pada atlet sepak bola
}

\author{
Effectiveness of maltodextrin and vitamin C combination drink to leukocyte differential counts in football athlete
}

Silvi Lailatul Mahfida, Istiti Kandarina, Arta Farmawati

\begin{abstract}
Backgrounds: The immune system changing affects the fitness. Exercise induces the immune responses, oxidative stress and tissue damage that alters leukocyte counts. Maltodextrin supplies higher energy reserves, that can improve the immune system profiles. Vitamin C as an antioxidant against tissue damage. Objective: This study aims to assess the effectiveness of a maltodextrin and vitamin C combination drink on leukocyte differential count after exercise. Method: This study was quasi experimental with within subject design. Subjects were 14 collegiate football players of State University of Yogyakarta and fulfilled the inclusion and exclusion criteria. Subjects were selected with a purposive sampling. Subjects received a combination of $15 \%$ maltodextrin and $250 \mathrm{mg}$ of vitamin C beverage, $300 \mathrm{~mL}$. Subjects did wash out for 6 days, then received placebo beverage (300 mL plain water). Subjects drank 30 minutes before and 5 minutes after physical exercise. Exercise loads were yoyo intermitten test and run gradually until $80 \mathrm{HR}$. Blood samples were taken immediately and 30 minutes after exercise. Results: In the administration of intervention beverage, immediately to 30 minutes after exercise neutrophils increased ( $p=0,006)$; lymphocytes decreased ( $p=0.015)$; monocytes decreased ( $p=0.000)$; and eosinophils decreased ( $p=0.613)$. In the administration of placebo beverage, immediately to 30 minutes after exercise, neutrophils increased ( $p=0.359$ ); lymphocytes decreased $(p=0.257)$; monocytes decreased $(p=0.146)$; and eosinophils increased $(p=0.549)$. Neutrophils $(p=0.003)$ and monocyte $(p=0.003)$ had significant difference between both administration drink at 30 minutes after exercise. Lymphocyte and monocyte significantly decrease $(p<0.05)$ at intervention than placebo. Conclution: Maltodextrin and vitamin C combination drink effect on the decreasing of lymphocyte and monocyte 30 minutes after exercise.
\end{abstract}

KEY WORDS: maltodextrin, vitamin $C$, after exercise, leukocyte differential counts, football athlete

\begin{abstract}
ABSTRAK
Latar belakang: Latihan fisik memicu respon imun, stres oksidatif, dan kerusakan jaringan yang menyebabkan perubahan hitung jenis leukosit. Maltodekstrin menyediakan cadangan energi lebih tinggi dan membantu memperbaiki profil sistem imun. Vitamin C sebagai antioksidan melawan kerusakan jaringan. Tujuan: Mengkaji efektivitas pemberian minuman kombinasi maltodekstrin dan vitamin C terhadap hitung jenis leukosit setelah latihan. Metode: Jenis penelitian quasi experimental dengan rancangan within subject design. Subjek penelitian adalah 14 atlet sepak bola mahasiswa dari Universitas Negeri Yogyakarta dan memenuhi kriteria inklusi serta eksklusi. Pemilihan subjek dengan purposive sampling. Subjek mendapat minuman sebanyak $300 \mathrm{~mL}$ kombinasi $15 \%$ maltodekstrin dan $250 \mathrm{mg}$ vitamin C. Wash out selama 6 hari, kemudian subjek diberi minuman plasebo (air putih $300 \mathrm{~mL}$ ). Minuman diberikan 30 menit sebelum dan 5 menit setelah latihan. Latihan berupa yoyo intermitten test dan lari bertahap hingga $80 \% \mathrm{HR}_{\text {maks }}$. Sampel darah diambil segera dan 30 menit setelah latihan. Hasil: Pada pemberian minuman intervensi, sesaat hingga 30 menit setelah latihan, neutrofil naik ( $\mathrm{p}=0,006)$; limfosit turun $(\mathrm{p}=0,015)$; monosit turun $(\mathrm{p}=0,000)$; dan eosinofil turun $(\mathrm{p}=0,613)$. Pada pemberian minuman plasebo, sesaat hingga 30 menit setelah latihan, neutrofil naik ( $\mathrm{p}=0,359)$; limfosit turun ( $\mathrm{p}=0,257)$; monosit turun ( $\mathrm{p}=0,146)$; dan eosinofil naik ( $\mathrm{p}=0,549)$. Neutrofil $(\mathrm{p}=0,003)$ dan monosit $(\mathrm{p}=0,003)$ berbeda signifikan antar kedua pemberian pada 30 menit setelah latihan. Pada pemberian minuman intervensi, 30 menit setelah latihan, limfosit dan monosit menurun signifikan $(\mathrm{p}<0,05)$ dibandingkan plasebo. Simpulan: Minuman kombinasi maltodekstrin dan vitamin $\mathrm{C}$ berefek pada penurunan limfosit dan monosit 30 menit setelah latihan.
\end{abstract}

KATA KUNCI: maltodekstrin, vitamin C, setelah latihan, hitung jenis leukosit, atlet sepak bola

\footnotetext{
${ }^{1}$ Korespondensi: Universitas 'Aisyiyah Yogyakarta, Kampus Terpadu Jl. Lingkar Barat No.63 Mlangi, Nogotirto, Gamping, Sleman, Daerah Istimewa Yogyakarta (DIY) 55292,e-mail: silvilailatul@gmail.com

2 Program Studi S2 Ilmu Kesehatan Masyarakat, Fakultas Kedokteran Universitas Gadjah Mada, Jl. Farmako, Sekip Utara, Yogyakarta 55281, e-mail: ikandarina@ yahoo.com

3 Bagian Biokimia, Fakultas Kedokteran Universitas Gadjah Mada, Jl. Farmako, Sekip Utara, Yogyakarta 55281, e-mail: a.farmawati@ugm.ac.id
} 


\section{PENDAHULUAN}

Sepak bola adalah olahraga yang membutuhkan kekuatan, daya ledak otot, kecepatan, kelincahan, serta daya tahan jantung dan paru (1). Sepak bola adalah salah satu olahraga popular yang dimainkan hampir di seluruh negara, tak terkecuali Indonesia. Pada kompetisi di Asia Youth Game, Indonesia masih tertahan di perempat final (2). Tim sepak bola Indonesia U-23 juga dikalahkan oleh tim Thailand pada final SEA Games XXVII (3) sedangkan di Yogyakarta sendiri, tim Daerah Istimewa Yogyakarta (DIY) hanya mampu meraih posisi runner up setelah dikalahkan oleh tim Daerah Khusus Ibu Kota (DKI) Jakarta (4). Prestasi atlet ini berkaitan dengan performa yang merupakan kombinasi dari kebugaran kardiovaskular, kekuatan otot, ketahanan, fleksibilitas, ketangkasan, koordinasi, keterampilan, dan taktik.

Performa atlet juga dipengaruhi oleh perubahan yang terjadi pada sistem imun tubuh. Pada saat latihan fisik, terjadi perubahan respon imun. Respon imun ini berlangsung pada latihan aerobik maupun anaerobik (5). Perubahan respon imun dapat memicu terjadinya risiko infeksi pada atlet (6) dan kemudian dapat berdampak pada performa atlet dan fase pemulihan (recovery) untuk mempersiapkan latihan berikutnya (7). Kerusakan otot yang disebut dengan delayed-onset of muscle damage (DOMS) juga terjadi pada latihan akut yang disebabkan oleh stres oksidatif. Kerusakan otot inilah yang menimbulkan respon inflamasi serta menyebabkan perubahan total dan hitung jenis leukosit (8). Respon yang terjadi adalah peningkatan leukosit neutrofil, monosit, sel natural killer, katekolamin, hormon, anti-inflamasi, dan pro-inflamasi serta protein fase akut (7). Total leukosit meningkat setelah melakukan latihan fisik selama 30 menit pada $75 \% \mathrm{VO}_{2 \text { maks }}$ baik pada subjek terlatih maupun tidak terlatih (9). Kadar leukosit meningkat hingga 30 menit setelah latihan singkat maupun intens, kembali ke level semula dan kemudian meningkat kembali pada 1-3 jam setelah latihan fisik (10). Latihan aerobik dengan intensitas $85 \% \mathrm{VO}_{2 \text { maks }}$ berefek pada akumulasi leukosit pada darah perifer. Perubahan kadar leukosit ini menjadi indikator melemahnya imun (11). Neutrofil, limfosit, dan monosit mengalami peningkatan selama beberapa menit pertama latihan (12).

Dalam rangka meningkatkan performa latihan dan kompetisi, diperlukan modifikasi asupan gizi pada atlet
(13). Maltodekstrin adalah polimer karbohidrat yang digunakan secara khusus dalam diet untuk aktivitas fisik. Pengosongan lambung dari polimer glukosa lebih cepat daripada larutan gula biasa yang dapat mencegah penurunan glukosa darah secara tiba-tiba dan hiperinsulinemia karena hipoglikemi selama latihan fisik (14). Pemberian larutan polimer glukosa dianjurkan karena dengan osmolalitas yang rendah memberikan efek yang lebih baik daripada larutan glukosa saja sebagai asupan energi sebelum dan selama olahraga (15). Suplementasi maltodekstrin sebelum latihan fisik dapat meningkatkan simpanan glikogen otot dan hati $(14,16)$. Asupan maltodekstrin sebelum dan selama latihan dapat meningkatkan kadar glukosa darah dan performa latihan (17). Penelitian menunjukkan bahwa konsumsi minuman dengan kandungan karbohidrat 6\% (1 liter/jam) selama minimal 1 jam latihan endurance dengan intensitas tinggi dapat menekan peningkatan total hitung leukosit dan hitung jenis leukosit seperti monosit dan neutrofil (7).

Lebih lanjut, vitamin $\mathrm{C}$ bermanfaat untuk meningkatkan sistem imun dan memiliki efek antioksidan. Vitamin C juga meningkatkan daya tahan terhadap infeksi melalui aktivitas imunologi dari leukosit, produksi interferon, proses reaksi inflamasi dan integritas membran. Vitamin $\mathrm{C}$ dapat mempengaruhi performa fisik pada atlet sehubungan dengan sintesis karnitin yang berperan dalam penyediaan energi dan meningkatkan fungsi imun, khususnya atlet olahraga endurance yang cenderung lebih mudah terkena infeksi saluran pernafasan atas $(18,19)$. Suplementasi vitamin C dapat mencegah kerusakan otot (20).

Oleh karena itu, diperlukan kajian lebih lanjut mengenai bagaimana efektivitas minuman kombinasi maltodekstrin dan vitamin $\mathrm{C}$ terhadap hitung jenis leukosit atlet sepak bola. Tujuan umum dari penelitian ini adalah untuk mengkaji efektivitas minuman kombinasi maltodekstrin dan vitamin $\mathrm{C}$ terhadap hitung jenis leukosit segera dan 30 menit setelah latihan pada atlet.

\section{BAHAN DAN METODE}

Jenis penelitian ini adalah penelitian quasi experimental dengan rancangan penelitian within subject design yang dilaksanakan pada Januari sampai Juli 2014. 
Subjek berjumlah 14 orang atlet sepak bola mahasiswa Universitas Negeri Yogyakarta. Subjek dipilih secara purposive sampling berdasarkan kriteria inklusi yaitu laki-laki, usia antara 18-24 tahun, aktif mengikuti latihan, dan bersedia menjadi subjek penelitian dengan menandatangani informed consent sedangkan kriteria eksklusi adalah mengalami cedera atau patah tulang, merokok, sedang dalam masa karantina atau pengawasan khusus yang membutuhkan pengaturan diet, konsumsi obat, atau suplemen tertentu.

Besar sampel pada penelitian ini dihitung menggunakan rumus untuk menguji hipotesis satu sampel variabel kontinyu dengan tingkat signifikansi $(\alpha)$ sebesar 0,05; power penelitian $80 \%$; simpang baku populasi standar $(\sigma)$ sebesar $1,08 \times 10^{9} \mathrm{sel} / \mathrm{L}(21)$; perbedaan klinis (clinical judgement $\left(\mu_{1}-\mu_{2}\right)$ yaitu $\mu_{1}=2,96 \times 10^{9} \mathrm{sel} / \mathrm{L}$ dan $\mu_{2}=3,92$ $\times 10^{9} \mathrm{sel} / \mathrm{L}(21)$ sehingga diperoleh besar sampel sebanyak 10 orang dan dengan estimasi drop out $20 \%$ didapatkan besar sampel minimal sebanyak 12 orang. Sebanyak 19 orang telah menyetujui informed consent, tetapi hanya 14 orang yang mengikuti penelitian ini sampai selesai.

Penelitian pendahuluan dilakukan untuk formulasi minuman dan pengukuran karakteristik subjek. Semua subjek menjalani koreksi faktor luar sehari sebelum pemberian minuman, yaitu berupa pengaturan aktivitas fisik yang tidak berlebihan, waktu tidur malam maksimal jam 22.00 WIB, serta tidak mengkonsumsi suplemen vitamin dan mineral, energy drink, dan alkohol. Koreksi tersebut dilakukan dengan memberikan pengingat dan check list kepada subjek yang bertujuan untuk meminimalkan pengaruh dari asupan makanan dan minuman, aktivitas fisik, serta kondisi psikologis akibat waktu tidur, yang dapat mempengaruhi status hidrasi, simpanan zat gizi, serta perubahan sistem imun dalam tubuh. Sebelum diberi perlakukan, dilakukan pengambilan data aktivitas fisik dan asupan zat gizi subjek sehari sebelumnya. Diet standar untuk sarapan diberikan 2 jam sebelum latihan, yang terdiri dari nasi, lauk hewani, lauk nabati, dan sayur, serta air putih 600 $\mathrm{ml}$. Nilai gizi sarapan berdasarkan kebutuhan $25 \%$ energi sehari (energi 500-600 kkal, karbohidrat 50-88 g, protein $15 \%$, dan lemak $30 \%$ ) sesuai dengan standar frekuensi latihan 3 kali seminggu.

Karakteristik subjek penelitian yang diukur antara lain usia, indeks massa tubuh (IMT), posisi subjek dalam tim, dan tingkat kebugaran subjek pada saat pengambilan data. Kebugaran diketahui berdasarkan penilaian $\mathrm{VO} 2 \mathrm{max}$ atlet atau daya tahan jantung paru yang menggambarkan jumlah maksimal oksigen yang dikonsumsi. Uji kebugaran digunakan untuk melihat kondisi performa subjek pada saat diberikan perlakuan sekaligus sebagai bentuk latihan fisik. Tingkat kebugaran subjek (mL/kg BB/menit) dikategorikan menjadi cukup/ fair (25-33); rata-rata/average (34-42); baik/good (4352); dan sangat baik/excellent (>52) (22).

Variabel bebas dalam penelitian ini adalah pemberian minuman kombinasi maltodekstrin dan vitamin $\mathrm{C}$ sedangkan variabel tergantung adalah hitung jenis leukosit. Hitung jenis leukosit adalah jumlah relatif jenis sel leukosit yaitu neutrofil, limfosit, monosit, dan eosinofil, diukur segera dan 30 menit setelah melakukan latihan fisik menggunakan sampel darah di ujung jari dan vena. Nilai normal neutrofil sebesar 50-62\%; limfosit 25 40\%; monosit 3-7\%; dan eosinofil 0-3\% (23). Faktor luar yaitu aktivitas fisik serta asupan makanan dan minuman. Aktivitas fisik adalah level kegiatan fisik yang dilakukan subjek sehari sebelum pemberian minuman selama 24 jam. Level aktivitas fisik menurut kategori $\triangle \mathrm{PAL}$ adalah sedentari (1,00-1,39); kurang aktif $(1,40-1,59)$; aktif $(1,60-1,89)$; dan sangat aktif $(1,9-2,5)(24)$. Sementara itu, level aktivitas fisik menurut durasi latihan adalah rendah ( $<2$ jam/minggu); sedang ( $2-5 \mathrm{jam} /$ minggu); dan tinggi ( $>5 \mathrm{jam} /$ minggu) (25). Lebih lanjut, dilakukan pengkajian jumlah konsumsi makanan dan minuman dalam 24 jam yang terdiri dari asupan energi (kkal), karbohidrat (g), protein (g), lemak (g). Kecukupan asupan makanan dihitung berdasarkan kebutuhan masing-masing subjek. Kebutuhan subjek untuk energi $35 \mathrm{kkal} / \mathrm{kg}$ berat badan/hari; protein $1 \mathrm{~g} / \mathrm{kg}$ berat badan/hari; lemak $30 \%$ kebutuhan energi; serta karbohidrat 55-65\% kebutuhan energi (26).

Subjek mendapat dua perlakukan seperti terlihat pada Gambar 1. Perlakuan pertama adalah pemberian minuman kombinasi maltodekstrin 15\% (45 g) dan vitamin C $250 \mathrm{mg}$ yang dilarutkan dengan air putih sampai volume $300 \mathrm{ml}$. Perlakuan kedua adalah pemberian minuman plasebo, yaitu air putih sebanyak $300 \mathrm{ml}$. Minuman diberikan 30 menit sebelum uji kebugaran dan 5 menit setelah pembebanan latihan 


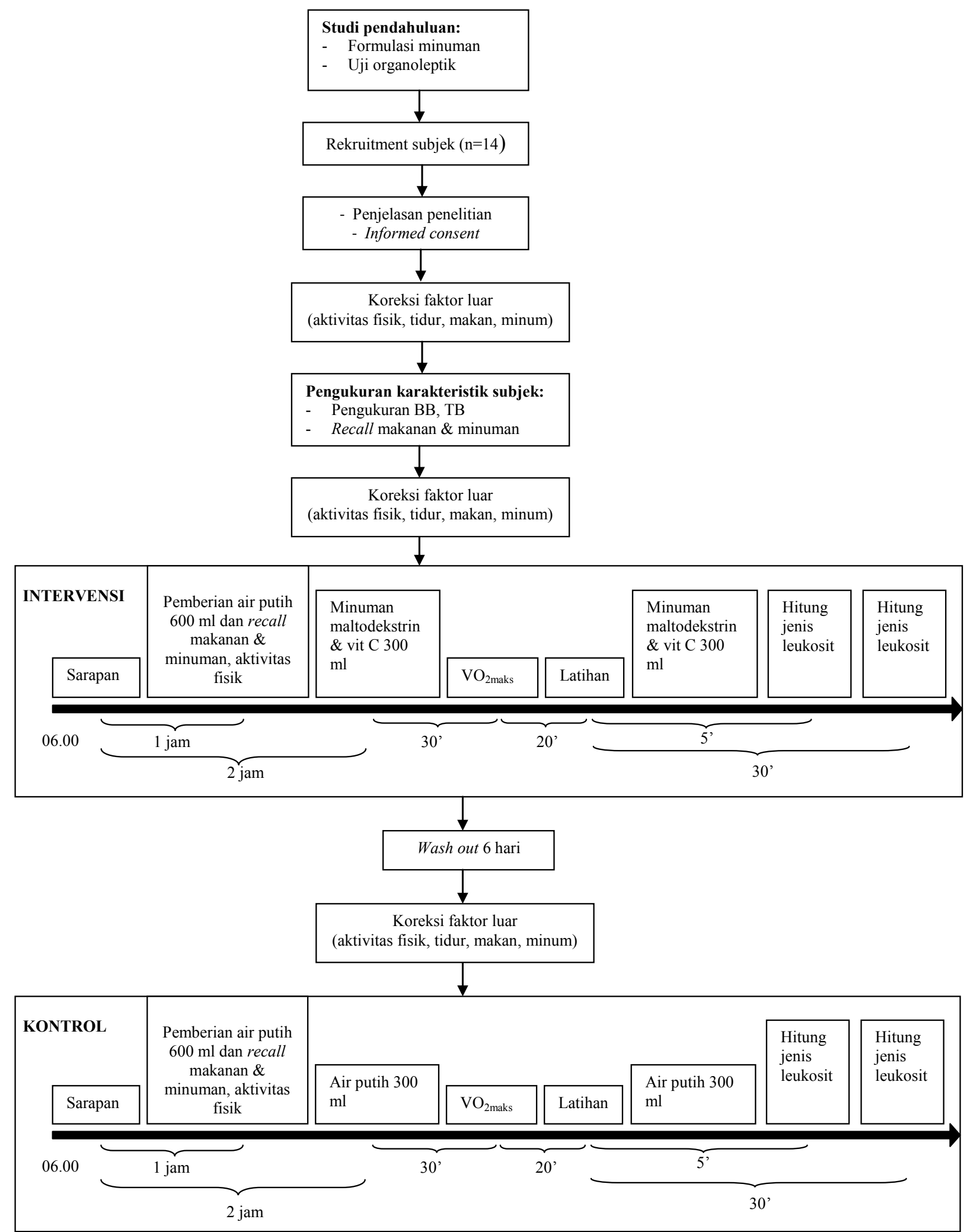

Gambar 1. Alur pelaksanaan penelitian 
fisik. Subjek menjalani wash out selama 6 hari. Sampel darah diambil segera dan 30 menit setelah latihan. Subjek menjalani latihan fisik berupa uji kebugaran dengan yo yo intermittent test dan pembebanan aktivitas fisik dengan lari secara bertahap hingga mencapai $80 \% \mathrm{HR}_{\text {maks }}$.

Data IMT, usia, karakteristik performa harian, asupan makanan dan minuman sehari, level aktivitas fisik, serta hitung jenis leukosit diuji menggunakan uji Saphiro-Wilk untuk mengetahui distribusi data. Perubahan, perbedaan, dan efek minuman kombinasi terhadap hitung jenis leukosit diuji dengan paired t-test dan Wilcoxon. Penelitian ini telah memperoleh kelaikan etik dari Komisi Etik Penelitian Kedokteran dan Kesehatan, Fakultas Kedokteran UGM dengan nomor KE/FK/396/EC.

\section{HASIL}

\section{Karakteristik subjek}

Rerata usia subjek 19,5 tahun dengan posisi sebagai bek dan gelandang masing-masing sebanyak 6 orang serta posisi penyerang sebanyak 2 orang. Median IMT subjek sebesar $21,75 \mathrm{~kg} / \mathrm{m}^{2}$ dan kebugaran subjek lebih tinggi secara signifikan $(\mathrm{p}=0,000)$ pada pemberian plasebo $(53,9 \pm 1,86 \mathrm{ml} / \mathrm{kg} / \mathrm{menit})$ dibandingkan dengan pemberian minuman kombinasi maltodekstrin dan vitamin C (51,95 $\pm 1,55 \mathrm{ml} / \mathrm{kg} / \mathrm{menit}$ ) (Tabel 1).

Hasil koreksi faktor sebelum pemberian minuman kombinasi maltodekstrin dan vitamin $\mathrm{C}$ serta minuman plasebo yaitu semua subjek tidak mengonsumsi suplemen, energy drink, maupun alkohol. Hasil pengujian aktivitas fisik menunjukkan bahwa tidak ada perbedaan aktivitas fisik yang siginifikan antara pemberian minuman kombinasi maltodekstrin dan vitamin $\mathrm{C}$ dengan plasebo. Subjek menjalani latihan dua kali seminggu, masingmasing dengan durasi latihan rata-rata dua jam. Latihan dengan durasi rata-rata empat jam seminggu termasuk dalam kategori aktivitas fisik sedang. Demikian juga tidak ada perbedaan asupan energi $(\mathrm{p}=0,706)$; protein $(\mathrm{p}=0,730)$; lemak $(\mathrm{p}=0,090)$; karbohidrat $(\mathrm{p}=0,396)$; dan

Tabel 1. Kebugaran subjek

\begin{tabular}{lccc}
\hline $\begin{array}{l}\text { Tingkat kebugaran } \\
\left(\mathbf{V O}_{\text {2maks }}\right)\end{array}$ & $\begin{array}{c}\text { Maltodekstrin } \\
\text { +vit.C }\end{array}$ & Plasebo & p \\
\hline $\begin{array}{l}\text { Rerata } \pm \text { SD } \\
(\mathrm{mL} / \mathrm{kg} / \text { menit })\end{array}$ & $51,95 \pm 1,55$ & $53,9 \pm 1,86$ & $0,000^{*}$ \\
Baik (\%) & 57,14 & 21,43 & \\
\hline Sangat baik (\%) & 42,86 & 78,57 & \\
\hline
\end{tabular}

"berbeda signifikan antar kedua pemberian $(\mathrm{p}<0,05)$

Tabel 2. Aktivitas fisik dan asupan energi, protein, lemak, dan karbohidrat

\begin{tabular}{lcccc}
\hline \multicolumn{1}{c}{ Data } & Min & Max & Rerata \pm SD & p \\
\hline Aktivitas fisik (APAL) & & & & \\
$\quad$ Maltodekstrin+vit.C & 1,3 & 2,43 & $1,66^{*} \pm 0,30$ & 0,179 \\
$\quad$ Plasebo & 1,2 & 3,69 & $1,72^{*} \pm 0,63$ & \\
Asupan energi (kkal) & & & & \\
$\quad$ Maltodekstrin+vit.C & 1845,2 & $3.622,1$ & $2.571,3 \pm 518,23$ & 0,706 \\
$\quad$ Plasebo & 1634,7 & $3.742,8$ & $2.629,3 \pm 481,59$ & \\
Asupan protein (g) & & & & \\
$\quad$ Maltodekstrin+vit.C & 53,5 & 104,6 & $62,7^{*} \pm 14,61$ & 0,790 \\
$\quad$ Plasebo & 44,0 & 104,0 & $72 \pm 18,17$ & \\
Asupan lemak (g) & & & & \\
$\quad$ Maltodekstrin+vit.C & 44,2 & 107,7 & $66,66 \pm 19,63$ & 0,090 \\
$\quad$ Plasebo & 40,8 & 107,7 & $77,84 \pm 21,65$ & \\
Asupan karbohidrat (g) & & & & \\
$\quad$ Maltodekstrin+vit.C & 262,5 & 640,7 & $438,15 \pm 112,23$ & 0,396 \\
$\quad$ Plasebo & 267,6 & 613,4 & $413,42 \pm 90,64$ & \\
Asupan vitamin C (mg) & & & & \\
$\quad$ Maltodekstrin+vit.C & 3,1 & 388,9 & $141,68 \pm 138,55$ & 0,915 \\
$\quad$ Plasebo & 4,0 & 572,9 & $125,45^{*} \pm 144,08$ & 0,9 \\
\hline
\end{tabular}

Keterangan: * = median; vit. $\mathrm{C}=$ vitamin $\mathrm{C} ; \mathrm{PAL}=$ physical activity level 
Tabel 3. Perbandingan hitung jenis leukosit pada pemberian minuman kombinasi maltodekstrin dan vitamin $\mathrm{C}$ dan pemberian plasebo

\begin{tabular}{|c|c|c|c|c|c|c|c|c|c|c|c|c|}
\hline \multirow{3}{*}{$\begin{array}{c}\text { Rerata } \pm \\
\text { SD }\end{array}$} & \multicolumn{12}{|c|}{ Jenis leukosit (\%) } \\
\hline & \multicolumn{3}{|c|}{ Neutrofil } & \multicolumn{3}{|c|}{ Limfosit } & \multicolumn{3}{|c|}{ Monosit } & \multicolumn{3}{|c|}{ Eosinofil } \\
\hline & P1 & P2 & $\mathbf{p}$ & P1 & P2 & $\mathbf{p}$ & P1 & P2 & $\mathbf{p}$ & P1 & P2 & p \\
\hline POST & $54,93 \pm 15,23$ & $57,5 \pm 9,85$ & 0,591 & $40,00 \pm 15,29$ & $36,5 \pm 10,20$ & 0,465 & $2,36 \pm 1,78$ & $3,36 \pm 1,98$ & 0,205 & $2,71 \pm 3,99$ & $2,57 \pm 2,65$ & 0,754 \\
\hline POST30 & $68,00 \pm 6,88$ & $60,57 \pm 8,33$ & $0,003^{*}$ & $29,07 \pm 6,99^{\#}$ & $32,86 \pm 8,38$ & 0,083 & $0,5 \pm 1,16^{\#}$ & $2,29 \pm 1,59$ & $0,003^{*}$ & $2,36 \pm 2,31$ & $3,36 \pm 2,18$ & 0,388 \\
\hline
\end{tabular}

P1 = Maltodekstrin+vit.C; P2 = Plasebo;

" $\mathrm{p}<0,05$ berbeda signifikan dimana maltodekstrin+vit.C $\neq$ plasebo;

${ }^{\#} \mathrm{p}<0,05$ berbeda signifikan dimana maltodekstrin+vit. $\mathrm{C}<$ plasebo;

POST $=$ segera setelah latihan; POST30 $=30$ menit setelah latihan.

vitamin $\mathrm{C}(\mathrm{p}=0,915)$ yang signifikan antara pemberian minuman kombinasi maltodekstrin dan vitamin $\mathrm{C}$ dengan placebo (Tabel 2).

Hitung jenis leukosit pada pemberian minuman kombinasi maltodekstrin dan vitamin $\mathrm{C}$ dan pemberian plasebo

Pada pemberian kombinasi maltodekstrin dan vitamin $\mathrm{C}$, dari segera hingga 30 menit setelah latihan, neutrofil cenderung naik $(\mathrm{p}=0,006)$; limfosit cenderung turun; monosit cenderung turun; dan eosinofil cenderung turun. Kenaikan yang signifikan terjadi pada neutrofil sedangkan penurunan yang signifikan ditunjukkan oleh limfosit $(\mathrm{p}=0,015)$ dan monosit $(\mathrm{p}=0,000)$. Sementara pada pemerian plasebo, dari segera hingga 30 menit setelah latihan, neutrofil cenderung naik, limfosit cenderung turun, monosit cenderung turun, dan eosinofil cenderung naik. Tidak ada kenaikan maupun penurunan hitung jenis yang signifikan dari segera hingga 30 menit setelah latihan (semua nilai $\mathrm{p}>0,05$ ).

Sementara itu, perbandingan hitung jenis leukosit antara pemberian minuman kombinasi maltodekstrin dan vitamin dengan plasebo menunjukkan bahwa perbedaan jumlah neutrofil yang signifikan $(\mathrm{p}=0,003)$ antara kedua pemberian terlihat pada 30 menit setelah latihan. Pemberian minuman kombinasi maltodekstrin dan vitamin $\mathrm{C}$ tidak berefek signifikan pada penurunan jumlah neutrofil. Tidak ada perbedaan jumlah limfosit yang signifikan antara kedua pemberian, baik sesaat setelah latihan $(\mathrm{p}=0,466)$ maupun 30 menit setelah latihan $(p=0,083)$. Pemberian minuman kombinasi maltodekstrin dan vitamin $\mathrm{C}$ berefek signifikan terhadap penurunan limfosit 30 menit setelah latihan. Tidak ada perbedaan jumlah monosit yang signifikan antara kedua pemberian, baik segera setelah latihan $(\mathrm{p}=0,205)$ maupun 30 menit setelah latihan $(\mathrm{p}=0,236)$. Pemberian minuman kombinasi maltodekstrin dan vitamin $\mathrm{C}$ berefek signifikan terhadap penurunan monosit 30 menit setelah latihan. Tidak ada perbedaan jumlah eosinofil yang signifikan antara kedua pemberian, baik segera setelah latihan $(\mathrm{p}=0,107)$ maupun 30 menit setelah latihan $(\mathrm{p}=0,114)$. Pemberian minuman kombinasi maltodekstrin dan vitamin $\mathrm{C}$ tidak berefek signifikan pada penurunan jumlah eosinofil baik segera maupun 30 menit setelah latihan (Tabel 3).

\section{BAHASAN}

Pada latihan dengan intensitas sedang sampai tinggi, kadar neutrofil dalam darah cenderung meningkat selama tahap recovery, mulai dari sesaat (27), 30 menit (8), 90 menit (28), hingga beberapa jam setelah latihan (29). Sementara pada penelitian ini, dari segera hingga 30 menit setelah latihan, neutrofil naik secara signifikan, baik pada pemberian minuman kombinasi maltodekstrin dan vitamin $\mathrm{C}$ maupun plasebo. Kenaikan neutrofil ini sebagai respon dari stres oksidatif setelah latihan (30) dan kerusakan sel akibat apoptosis selama latihan $(8,10)$. Kenaikan neutrofil yang signifikan terjadi terutama saat latihan dengan intensitas sedang dan tinggi yang dilakukan selama 1 jam (31). Neutrofil cenderung lebih mudah meningkat setelah latihan karena merupakan pertahanan pertama dalam sistem imun (32). Asupan karbohidrat dapat menambah cadangan glukosa darah selama latihan sehingga mampu mengkompensasi pengeluaran energi yang banyak dan menekan pengeluaran hormon stres sehingga stres pada sistem imun dapat dikurangi (10). Beberapa penelitian mengatakan, jumlah neutrofil lebih 
rendah pada subjek yang diberi asupan karbohidrat daripada tanpa karbohidrat $(28,33)$.

Lebih lanjut, asupan vitamin $\mathrm{C}$ dapat mencegah kerusakan otot akibat apoptosis dan melindungi sel dari stres oksidatif (20). Hasil penelitian ini menunjukkan perbedaan jumlah neutrofil yang signifikan antara pemberian minuman kombinasi maltodekstrin dan vitamin $\mathrm{C}$ dengan plasebo, yaitu neutrofil pada pemberian minuman kombinasi maltodekstrin dan vitamin $\mathrm{C}$ lebih tinggi daripada plasebo. Jumlah neutrofil terbukti tidak lebih rendah pada pemberian minuman kombinasi maltodekstrin dan vitamin C. Beberapa hasil penelitian lain juga menunjukkan asupan karbohidrat tidak berpengaruh signifikan terhadap produksi neutrofil (3436). Jumlah neutrofil dapat dikoreksi dengan level kortisol dan glukosa darah (28), tetapi tidak dilakukan dalam penelitian ini. Selain terjadi kenaikan glukosa darah, suplementasi karbohidrat juga berefek terhadap kenaikan insulin. Insulin memiliki peran dalam meregulasi fungsi neutrofil dalam keadaan hiperinsulinemia-normoglikemia (37).

Suplementasi vitamin $\mathrm{C}$ dapat meningkatkan konsentrasi vitamin $\mathrm{C}$ di dalam neutrofil yang mengatur produksi reactive oxygen species (ROS) ketika latihan. Vitamin $\mathrm{C}$ memberikan pengaruh terhadap pengaturan produksi neutrofil. Vitamin $\mathrm{C}$ sebagai agen scavenger dari hypochlorous-acid ( $\mathrm{HOCl}$ ) yang dihasilkan oleh adanya kerusakan protein dan deoxyribonucleic acid (DNA) (38). Suplementasi satu jenis antioksidan (vitamin C) belum menunjukkan hasil yang konsisten dalam penurunan level neutrofil (39). Suplementasi lebih dari satu macam antioksidan dapat mengkompensasi peningkatan neutrofil akibat produksi radikal bebas (40). Jumlah neutrofil yang lebih rendah secara signifikan pada pemberian plasebo kemungkinan juga dipengaruhi oleh level kebugaran subjek dan asupan protein dari diet. Hasil penelitian ini menunjukkan rerata asupan protein dari diet dan level $\mathrm{VO}_{2 \text { maks }}$ pada plasebo lebih tinggi. Asam amino berhubungan dengan stimulasi sintesis glikogen otot, mengurangi kerusakan otot, dan meningkatkan perbaikan jaringan saat olahraga (41). Level $\mathrm{VO}_{2 \text { maks }}$ memiliki asosiasi negatif dengan jumlah leukosit setelah latihan, terutama neutrofil dan monosit (42). Tingginya level $\mathrm{VO}_{2 \text { maks }}$ memberikan efek protektif terhadap inflamasi (43). Level $\mathrm{VO}_{2 \text { maks }}$ lebih tinggi pada plasebo kemungkinan karena adanya motivasi yang lebih tinggi untuk mencapai $\mathrm{VO}_{2 \text { maks }}$ yang lebih baik pada pengukuran kedua (saat pemberian plasebo) daripada pengukuran pertama (saat pemberian minuman kombinasi maltodekstrin dan vitamin C). Motivasi intrinsik dari atlet merupakan faktor penentu untuk memelihara level latihan. Subjek merasa lebih berkompeten, menikmati latihan, dan berupaya lebih(44). Perubahan level neutrofil pada jenis latihan sedang (2-5 jam per minggu) masih tidak konsisten sedangkan pada latihan dengan intensitas tinggi (lebih dari 5 jam per minggu) akan menunjukkan hasil kenaikan level neutrofil yang lebih konsisten, baik fungsi pada level akut maupun kronis (25).

Pada penelitian ini, jumlah limfosit cenderung mengalami penurunan dari segera hingga 30 menit setelah latihan baik pada pemberian minuman kombinasi maltodekstrin dan vitamin C maupun plasebo, tetapi penurunan yang signifikan terjadi pada pemberian minuman kombinasi maltodekstrin dan vitamin $\mathrm{C}$. Tidak ada perbedaan jumlah limfosit yang signifikan antara kedua pemberian. Namun, pemberian minuman kombinasi maltodekstrin dan vitamin $\mathrm{C}$ berefek signifikan terhadap lebih rendahnya limfosit 30 menit setelah latihan. Menurut hasil penelitian sebelumnya(45), jumlah limfosit akan meningkat selama latihan dengan durasi yang panjang, kemudian akan menurun setelah latihan dan levelnya akan meningkat pada 3 jam setelah latihan. Peningkatan jumlah limfosit setelah latihan terjadi akibat peningkatan jumlah sel natural killer (7) dan proliferasi limfosit(22). Namun, penelitian di Spanyol menyatakan bahwa terjadi penurunan level limfosit setelah selesai latihan (46). Suplementasi karbohidrat dan vitamin C terbukti mampu menurunkan limfosit secara signifikan dibandingkan plasebo $(28,47)$. Suplementasi karbohidrat dapat mengurangi aktivitas limfosit melalui pengurangan mitogen dan apoptosis sel (48). Aktivitas vitamin C di dalam limfosit meningkat selama latihan(47).

Jumlah monosit cenderung mengalami penurunan dari segera hingga 30 menit setelah latihan baik pada pemberian minuman kombinasi maltodekstrin dan vitamin $\mathrm{C}$ maupun plasebo, tetapi penurunan yang signifikan terjadi pada pemberian minuman kombinasi maltodekstrin dan vitamin C. Jumlah monosit cenderung 
lebih tinggi pada pemberian plasebo. Terdapat perbedaan jumlah monosit yang signifikan antara kedua tahap pemberian. Jumlah monosit 30 menit setelah latihan lebih rendah secara signifikan pada pemberian minuman kombinasi maltodekstrin dan vitamin C. Penurunan jumlah monosit selama recovery juga ditunjukkan oleh penelitian sebelumnya (21). Produksi adrenalin saat latihan dengan durasi panjang dapat memicu pengeluaran sitokin oleh monosit. Suplementasi karbohidrat dapat menurunkan level plasma adrenalin dan mencegah pengaktifan monosit untuk mengeluarkan sitokin (49). Antioksidan juga memiliki efek terhadap penurunan produksi IL-6 oleh sitokin (50) sehingga suplementasi karbohidrat dan antioksidan bersamaan mampu menghambat peningkatan produksi monosit.

Jumlah eosinofil cenderung turun pada pemberian minuman kombinasi maltodekstrin dan vitamin $C$, dan cenderung naik pada pemberian plasebo, dari sesaat hingga 30 menit setelah latihan. Namun, perubahan level eosinofil selama 30 menit setelah latihan tidak signifikan. Tidak ada perbedaan jumlah eosinofil yang signifikan antara pemberian minuman kombinasi maltodekstrin dan vitamin $\mathrm{C}$ dengan plasebo. Jumlah eosinofil meningkat selama beberapa menit setelah recovery pada latihan aerobik dengan durasi pendek. Mekanisme perubahan eosinofil saat latihan fisik dan pengaruh suplementasi karbohidrat maupun antioksidan belum banyak dibahas pada penelitian, karena tidak banyak penelitian yang membuktikan adanya perubahan signifikan dari level eosinofil (12). Namun, hasil penelitian sebelumnya pada atlet lari maraton menjelaskan bahwa peningkatan level eosinofil berkaitan dengan respon alergi pada sistem pernafasan (51).

Melalui hasil penelitian ini dan beberapa penelitian lain, perubahan hitung jenis leukosit secara keseluruhan belum menunjukkan hasil yang konsisten untuk mengetahui efek pemberian minuman berbasis karbohidrat maupun antioksidan. Oleh karena itu, perlu kajian lebih lanjut lagi tentang perubahan level hitung jenis leukosit dengan mempertimbangkan level latihan, intensitas latihan, performa atlet, durasi latihan, respon leukosit pada waktu pengambilan spesiemen yang berbeda, respon selama recovery, serta jumlah suplementasi karbohidrat dan antioksidan (vitamin C).

\section{SIMPULAN DAN SARAN}

Pada pemberian minuman kombinasi maltodekstrin dan vitamin $C$, dari segera hingga 30 menit setelah latihan, jumlah neutrofil naik secara signifikan sedangkan jumlah limfosit dan monosit menurun secara signifikan. Pada pemberian minuman plasebo, tidak ada perubahan hitung jenis yang signifikan dari segera hingga 30 menit setelah latihan. Terdapat perbedaan jumlah neutrofil dan monosit yang signifikan antara kedua pemberian minuman. Jumlah limfosit dan monosit 30 menit setelah latihan lebih rendah secara signifikan pada pemberian minuman kombinasi maltodekstrin dan vitamin C. Perlu kajian lebih lanjut lagi tentang perubahan level hitung jenis leukosit dengan mempertimbangkan level latihan, intensitas latihan, performa atlet, durasi latihan, respon selama recovery, serta jumlah suplementasi karbohidrat dan antioksidan (vitamin C).

\section{RUJUKAN}

1. Departemen Kesehatan RI. Gizi atlet sepak bola. Jakarta: Depkes RI; 2002.

2. Kemenpora. Langkah tim sepak bola Indonesia AYG terganjal di perempat final. [serial online] 2013 [cited 2013 Agustus 20]. Available from: URL: http://kemenpora.go.id/ index/ preview/search/8075

3. Saputra IY. Indonesia U-23 vs Thailand, kalah tipis $0-1$, penantian emas timnas berlanjut. [serial online] 2013 [cited 2013 Agustus 20]. Available from: URL: http://www. solopos.com/2013/12/21/sea-games-2013-indonesia-u23-vs-thailand-kalah-tipis-0-1-penantian-emas-timnasberlanjut-476372

4. Herawati M. POMNAS 2013 sepak bola DIY masuk final. [serial online] 2013 [cited 2013 Agustus 20]. Available from: URL: http://www.harianjogja.com/baca/2013/11/28/ pomnas-2013-sepak-bola-diy-masuk-final-469432

5. Deilami A, Sangari M, Shojaeimehr MT.The effect of two intensive aerobic and anaerobic tests on immune system in male athletic students in iran. World Applied Sciences Journal 2013;21(10):1530-9.

6. Pedersen BK, Hoffman-Goetz L. Exercise and the immune system: regulation, integration, and adaptation. Physiol Rev 2000;80(3):1055-81.

7. Gunzer W, Konrad M, Pail E. Exercise-induced immunodepression in endurance athletes and nutritional intervention with carbohydrate, protein and fat - what is possible, what is not?. Nutrients 2012;4(9):1187-1212.

8. Ascensão A, Rebelo A, Oliveira E, Marques F, Pereira L, Magalhães J. Biochemical impact of a soccer match - 
analysis of oxidative stress and muscle damage markers throughout recovery. Clin Biochem 2008;41(10-11):84151.

9. Gurcan N, Erbas D, Ergen E, Bilgehan A, Dundar S, Aricioglu A, Dikmenoglu N. Change in blood haemorheological parameter after submaximal exercise in trained and untrained subjects. Physiol Res 1998;47:2327.

10. Nieman DC, Pedersen BK. Nutrition and exercise immunology. Boca raton, Florida: CRC Press LLC; 2000.

11. Hsu TG, Hsu KM, Kong CW, Lu FJ, Cheng H, Tsai K. Leukocyte mitochondria alterations after aerobic exercise in trained human subjects. Med Sci Sports Exerc 2002;34(3):438-42.

12. Gabriel H, Kindermann W. The acute immune response to exercise: what does it mean?. Int J Sports Med 1997;18 Suppl 1:S28-45.

13. Alghannam AF. Physiology of soccer: the role of nutrition in performance. J Nov Physiother 2013;S3:003.

14. Ruffo AM, Osiecki R, Fernandes LC. Moderate to high dose of maltodextrin before exercise improves glycogen availability in soleus and liver after prolonged swimming in rats. J Exerc Physiol online 2009;12(4):30-8.

15. Leese GP, Bowtell J, Mudambo S. Post-exercise gastric emptying of carbohydrate solutions determined using the ${ }^{13} \mathrm{C}$ acetate breath test. Eur J Appl Physiol 1995;71:30610.

16. Khorshidi-Hosseini M, Nakhostin-Roohi B. Effect of glutamine and maltodextrin acute supplementation on anaerobic power. Asian J Sports Med 2013;4(2):131-6.

17. Wright DA, Sherman WM, Dernbach AR. Carbohydrate feedings before, during, or in combination improve cycling endurance performance. J Appl Physiol 1991;71(3):1082-8.

18. Greenwood M, Kalman DS, Antonio J. Nutritional supplements in sport and exercise. Humana Press: Totowa, USA; 2008.

19. Hasanloei F, Dodman MK, Kalantar J. Effect of vitamin $\mathrm{C}$ intake following exhaustive aerobic exercise on serum immunoglobulins $\mathrm{A}$ and $\mathrm{G}$ in karate athletes. International Journal of Sport Studies 2013;3(3):327-33.

20. Nakhostin-Roohi B, Babaei P, Rahmani-Nia F, Bohlooli S. Effect of vitamin $\mathrm{C}$ supplementation on lipid peroxidation, muscle damage and inflammation after 30-min exercise at 75\% VO2max. J Sports Med Phys Fitness 2008;48(2):21724.

21. Fatemeh A, Salesi M, Kushki M. Effect of high intensity training on changes leukocytes subsets in men football player. International Research Journal of Applied and Basic Sciences 2014;8(8):1023-7.
22. Gleeson M, Nieman DC, Pedersen BK. Exercise, nutrition and immune function. J Sports Sci 2004;22(1):115-25.

23. Fischbach F, Dunning MB. A manual of laboratory and diagnostic tests, 8th edition. China: Lippincott Williams \& Wilkins; 2009.

24. Otten JJ, Hellwig JP, Meyers LD. Dietary reference intakes: the essential guide to nutrient requirements. USA: National Academy of Sciences; 2006.

25. Duzova H, Erdogan H, Fadillioglu E, Emre EH. Effects of maximal anaerobic exercise on neutrophil oxidants/ antioxidants in among the sportsmen trained at various levels. Med Science 2012;1(2):77-89.

26. Kreider RB, Wilborn CD, Taylor Lem, Campbell B, Almada AL, Antonio J, et all. ISSN exercise \& sport nutrition review: research \& recommendations. Journal of the International Society of Sports Nutrition 2010;7:7.

27. Fehrenbach E, Passek F, Niess AM, Pohla H, Weinstock C, Dickhuth HH, Northoff H. HSP expression in human leukocytes is modulated by endurance exercise. Med Sci Sports Exerc 2000;32(3):592-600.

28. Carlson LA, Headley S, DeBruin J, Tuckow AT, Koch AJ, Kenefick RW. Carbohydrate supplementation and immune responses after acute exhaustive resistance exercise. Int J Sport Nutr Exerc Metab 2008;18(3):247-59.

29. Quindry JC, Stone WL, King J, Broeder CE. The effects of acute exercise on neutrophils and plasma oxidative stress. Med Sci Sports Exerc 2003;35(7):1139-45.

30. Koch, Alexander J. Immune response to exercise. Brazilian Journal of Biomotricity 2013;4(2):92-103.

31. Abdossaleh Z, Fatemeh A, Frozan K, Amin SM. Leukocytes subsets is differentially affected by exercise Intensity. International Journal of Sport Studies 2014;4(2):246-53.

32. Paul WE. Fundamental immunology, 7 th edition. China: Lippincott Williams \& Wilkins; 2013.

33. Scharhag J, Meyer T, Gabriel HH, Auracher M, Kindermann W. Mobilization and oxidative burst of neutrophils are influenced by carbohydrate supplementation during prolonged cycling in humans. Eur J Appl Physiol 2002;87(6):584-7.

34. Rombaldi AJ, Leite CF, Hartleben CP, Medeiros TH. Effects of carbohydrate supplementation and different types of exercise training on blood cells concentrations. Rev Bras Med Esporte 2013;19(3).

35. Lancaster GI, Jentjens RL, Moseley L, Jeukendrup AE, Gleeson M. Effect of pre-exercise carbohydrate ingestion on plasma cytokine, stress hormone, and neutrophil degranulation responses to continuous, high-intensity exercise. Int J Sport Nutr Exerc Metab 2003;13(4):436-53.

36. Bishop NC, Walsh N, Scanlon GA. Effect of prolonged exercise and carbohydrate on total neutrophil elastase content. Med Sci Sports Exerc 2003;35(8):1326-32. 
37. Walrand S, Guillet C, Boirie Y, Vasson MP. Insulin differentially regulates monocyte and polymorphonuclear neutrophil functions in healthy young andelderly humans. J Clin Endocrinol Metab 2006;91(7):2738-48.

38. PeakeJ, SuzukiK. Neutrophil activation, antioxidant supplements and exercise-induced oxidative stress. Exerc Immunol Rev 2004;10:129-41.

39. Krause R, Patruta S, Daxböck F, Fladerer P, Biegelmayer C, Wenisch C. Effect of vitamin C on neutrophil function after high-intensity exercise. Eur J Clin Invest 2001;31(3):25863.

40. Robson PJ, Bouic PJ, Myburgh KH. Antioxidant supplementation enhances neutrophil oxidative burst in trained runners following prolonged exercise. Int J Sport Nutr Exerc Metab 2003;13(3):369-81.

41. Gleeson M. Dosing and efficacy of glutamine supplementation in human exercise and sport training. J Nutr 2008;138(10):2045S-2049S.

42. Tenorio TR, Farah BQ, Ritti-Dias RM, Botero JP, Brito DC, Moura PM, Prado WL. Relation between leukocyte count, adiposity, and cardiorespiratory fitness in pubertal adolescents. Einstein (Sao Paulo) 2014;12(4):420-4.

43. Adamopoulos S, Parissis J, Kroupis C, Georgiadis M, Karatzas D, Karavolias G, Koniavitou K, Coats AJ, Kremastinos DT. Physical training reduces peripheral markers of inflammation in patients with chronic heart failure. Eur Heart J 2001;22(9):791-7.
44. Oman R, McAuley E. Intrinsic motivation and exercise behavior. Journal of Health Education 1993;24(4):232-238.

45. Henson DA, Nieman DC, Parker JC, Rainwater MK, Butterworth DE, Warren BJ, Utter A, Davis JM, Fagoaga OR, Nehlsen-Cannarella SL. Carbohydrate supplementation and the lymphocyte proliferative response to long endurance running. Int J Sports Med 1998;19:574-580.

46. Tauler P, Sureda A, Cases N, Aguilo A, Rodriguez-Marroyo JA, Villa G, Tur JA, Antoni P. Increased lymphocyte antioxidant defences in response to exhaustive exercise do not prevent oxidative damage. Journal of Nutritional Biochemistry 2006;17(10):665-71.

47. Peake JM. Vitamin C: effects of exercise and requirements with training. Int J Sport Nutr Exerc Metab 2003;13(2):12551.

48. Green KJ, Croaker SJ, Rowbottom DG. Carbohydrate supplementation and exercise-induced changes in T-lymphocyte function. J Appl Physiol 2003;95(3):121623.

49. Starkie RL, Angus DJ, Rolland J, Hargreaves M, Febbraio MA. Effect of prolonged, submaximal exercise and carbohydrate ingestion on monocyte intracellular cytokine production in humans. J Physiol 2000;528(Pt 3):647-55.

50. Gleeson M. Immune function in sport and exercise. J Appl Physiol 2007;103:693-9.

51. McKune AJ, Smith LL, Semple SJ, Wadee AA. Non-allergic activation of eosinophils after strenuous endurance exercise. South African Journal of Sports Medicine 2004;16(2):12-6. 